\title{
Activity of selected plant extracts against honey bee pathogen Paenibacillus larvae
}

\author{
Valery A. Isidorov ${ }^{1}$, Krzysztof BuCzeK ${ }^{2}$, Agnieszka SEGIET ${ }^{3}$, Grzegorz ZAMBrowski ${ }^{4}$, \\ Izabela SwIECICKA ${ }^{4,5}$ \\ ${ }^{1}$ Forest Faculty, Białystok University of Technology, 17-200, Hajnówka, Poland \\ ${ }^{2}$ Department of Epizootiology and Clinic of Infectious Diseases, Faculty of Veterinary Medicine, University of Life \\ Sciences, Lublin, Poland \\ ${ }^{3} 1$ st Faculty of Medicine, Medical University of Warsaw, Warsaw, Poland \\ ${ }^{4}$ Department of Microbiology, University of Białystok, Białystok, Poland \\ ${ }^{5}$ Laboratory of Applied Microbiology, University of Białystok, Białystok, Poland
}

Received 26 February 2018 - Revised 13 June 2018 - Accepted 20 July 2018

\begin{abstract}
The present study focuses on the antibacterial activity of selected plant extracts against Paenibacillus larvae, the causal agent of American foulbrood disease of honey bees. A gas chromatography-mass spectrometry method was used to analyze six diethyl ether extracts of two white birch species, black poplar and common aspen buds, as well as $n$-hexane, diethyl ether, and methanol extracts of young twigs from downy and silver birches. Among the identified extract constituents were flavonoids, phenylpropenoids, triterpenoids, and glucosides. In spite of significant differences in qualitative and quantitative composition, all tested in vitro extracts demonstrated high anti-P. larvae activity at minimal inhibitory concentration levels between $<1.0$ and $125 \mu \mathrm{g} / \mathrm{mL}$. To examine the cause of such disparity, the anti- $P$. larvae activity of some individual constituents naturally present in plant extract compounds was determined. A higher susceptibility of $P$. larvae (ERIC I) to relatively poorly polar triterpenoid levels compared to polar compounds, flavonoids, and glucosides was demonstrated.
\end{abstract}

\section{honey bees / Paenibacillus larvae / plant extracts / antimicrobial activity}

\section{INTRODUCTION}

Serious problems in worldwide beekeeping are connected to American foulbrood (AFB), a honey bee larvae disease caused by the Gram-positive spore-forming bacterium Paenibacillus larvae. The pathogen produces spores which are extremely environmentally resistant. Young larvae are infected by ingesting spores and they will die when sporulation occurs. This global disease is one of the primary honey bee threats (Genersch 2010; Evans and Schwartz 2011). The results of a 5-year epidemiological investigations show the scale of the threat in

Corresponding author: V. Isidorov, v.isidorov@pb.edu.pl

Manuscript editor: David Tarpy
Poland: from 4090 inspected apiaries, 38\% were infected (Skubida et al. 2014). For a long time, apiculturists treated the sick colonies with antibiotics. However, antibiotic treatment leads to negative consequences, such as appearance of bacterial resistance (Miyagi et al. 2000; Gende et al. 2010) and shifts in the gut microbial community structure which have detrimental impact on honey bees (Raymann et al. 2017). Current European legislation does not allow to use antibiotics for treatment of honey bees (Mutinelli 2003), because the products of these "farming animals" cannot contain drug residue. This prohibition has greatly limited the possibility of the treatment, but at the same time stimulate the development of alternative methods of combating AFB. Replacement of synthetic chemical drugs with natural antimicrobial substances is one promising direction (Alonso-Salces et al. 2017). 
As a natural remedy essential oils of different plants were examined. The antimicrobial action of essential oils can be mostly attributed to monoterpene hydrocarbons and their oxygenated derivatives, monoterpenoids. Anti- $P$. larvae activity has already been tested with the use of different citrus oils, thyme, oregano, rosemary, eucalyptus, and others (Alippi et al. 1996; Albo et al. 2003; Chaimanee et al. 2017; Fuselli et al. 2006, 2008; Gende et al. 2009; González and Marioli 2010; Pellegrini et al. 2017a, b; Santos et al. 2012). Unfortunately, the application of essential oils has not lead to the desired effect: the majority of them demonstrated relatively low activity against $P$. larvae with minimal inhibitory concentration (MIC) values from 250 to $850 \mu \mathrm{g} / \mathrm{mL}$ (Alonso-Salces et al. 2017). According to Albo et al. (2003), who evaluated the effectiveness of essential oils from savory, thyme, lemongrass, and oregano, neither single essential oils nor blends were effective in the elimination of AFB clinical symptoms at any dose formulation. Moreover, colonies treated with these oils showed higher levels of infection than those receiving a control treatment (Albo et al. 2003).

Substantially, more active against the pathogen is propolis (Antúnez et al. 2008; Bastos et al. 2008; Bilikova et al. 2013; Chen et al. 2018; Isidorov et al. 2016, 2017; Mihai et al. 2012; Wilson et al. 2015; Simone-Finstrom et al. 2017). Extracts of this natural antimicrobial bee product demonstrated lower (as a rule, an order of magnitude) MIC values in tests with $P$. larvae than essential oils. However, propolis is a highly valued bee product and demand for it is still growing. Moreover, it plays an extremely important role in bees "social immunity" (Borba et al. 2015; Simone-Finstrom and Spivak 2010). Hence, the excessive "robbery" of hives with this natural antibiotic responsible for the lower bacterial load levels within the hive is highly undesirable. The antibacterial activity of propolis has been reported to be primarily due to phenolics such as flavonoids, hydroxycinnamic, and phenolcarboxylic acids and their esters (Burdock 1998; Kujumgiev et al. 1999; Popova et al. 2007, 2017). However, these compounds are the secondary metabolite of plants and some recent investigations showed the anti-AFB potency of plant extracts (Boligon et al. 2013; Flesar et al.
2010; Reyes et al. 2013). In this respect, there is special interest in plants from which honey bee collect resins to prepare propolis. In the boreal and temperate climate zones of Europe, the principal plant precursors of propolis are bud resins of black poplar (Populus nigra) and its cultivars, white birch (Betula pubescens), and common aspen (Populus tremula) (Bankova et al. 2006; Isidorov et al. 2014a, 2016).

The main goal of this work was to investigate the in vitro anti- $P$. larvae activity, expressed as diameter of inhibition zone and as MIC value, of different extracts from some parts of the abovementioned "resin-giving" plants and attempt to connect the observed effects with the chemical composition of the extracts.

\section{MATERIALS AND METHODS}

\subsection{Chemicals and plant material}

Chemicals Betulinic, ursolic, and oleanolic acids, lupeol, dipterocarpol, betulinol, quercetin, (+)-catechin, salicin, arbutin, rhaponticin, and baicalin, and pyridine and bis(trimethylsilyl)trifluoroacetamide (BSTFA), as well as $\mathrm{C}_{8}-\mathrm{C}_{40} n$-alkane calibration standards, were purchased from Sigma-Aldrich (Poznań, Poland). Extractions were carried out with $n$-hexane, diethyl ether, and methanol (POCH SA, Gliwice, Poland). Diethyl ether was distilled before use.

Plant material Buds of downy birch (B. pubescens), silver birch (B. pendula), common aspen ( $P$. tremula), and black poplar (P. nigra) were gathered in April and/or September 2015 in the forests around Bialystok, Poland $\left(53^{\circ} 08^{\prime} 07^{\prime \prime} \mathrm{N} ; 23^{\circ} 08^{\prime} 44^{\prime \prime} \mathrm{E}\right)$. Buds were collected from 20- to 35-year-old trees (from 5 to 6 trees of each taxon). Besides that, plant material included twigs with young leaves from both species of birch collected in April 2015. In order to identify birch species, the genomic DNA was extracted from fragments of birch leaves and alcohol dehydrogenase was used to study the nuclear DNA sequences (Isidorov et al. 2014a).

Sample preparation and chemical analysis Buds (2-5 g) were cooled overnight at $-18^{\circ} \mathrm{C}$, ground 
and transferred into a $100-\mathrm{mL}$ retort, and extracted by stirring with three $50-\mathrm{mL}$ portions of diethyl ether for $30 \mathrm{~min}$. The joint extracts were filtered through a paper filter and then the ether was removed using a rotor evaporator to obtain the brownish residue which were used for chemical analysis and antibacterial tests. For chemical analysis, about $5 \mathrm{mg}$ of the residue was diluted with $220 \mu \mathrm{L}$ of pyridine and $80 \mu \mathrm{L}$ of BSTFA was added. The mixture was sealed and heated for $30 \mathrm{~min}$ at $60{ }^{\circ} \mathrm{C}$ to form trimethylsilyl (TMS) derivatives.

Young birch twigs from last year's accretion (ca. 5-6 g) were air-dried, cut into small pieces, ground, and extracted successively with three 100-mL portions of $n$-hexane, diethyl ether, and methanol. Next, the joint extracts were filtered and the solvent was evaporated to dryness. TMS derivatives were prepared from the obtained residue of the extracts using the technique described above.

The obtained solutions were analyzed by a GCMS method on a HP 7890 gas chromatograph with the 5975 VL MSD Triple-Axis Detector (Agilent Technologies, USA). The apparatus was fitted with an HP-5MS fused silica column (30 $\mathrm{m} \times 0.25 \mathrm{~mm}$ i.d., $0.25 \mu \mathrm{m}$ film thickness), with electronic pressure control and split/splitless injector. The latter worked at $250{ }^{\circ} \mathrm{C}$ in the split (1:50) mode. The helium flow rate through the column was $1 \mathrm{~mL} / \mathrm{min}$. The initial column temperature was $50{ }^{\circ} \mathrm{C}$, rising to $320^{\circ} \mathrm{C}$ at $3{ }^{\circ} \mathrm{C} / \mathrm{min}$, and the higher temperature was maintained for $15 \mathrm{~min}$. The MSD detector acquisition parameters were as follows: the transfer line temperature was $280{ }^{\circ} \mathrm{C}$, the MS source temperature $230{ }^{\circ} \mathrm{C}$, and the MS quad temperature $150{ }^{\circ} \mathrm{C}$. The electron impact mass spectra were obtained at $70 \mathrm{eV}$ of ionization energy. After integration, the fraction of separated components in the total ion current (TIC) was calculated.

To identify the separated components, both mass spectral data and calculated linear temperatureprogrammed retention indices $\left(I^{T}\right)$ were used. Mass spectrometric identification was carried out with an automatic system of GC-MS data processing supplied by NIST and home-made mass spectra libraries. The latter contains more than 1800 spectra of TMS derivatives prepared from commercial preparations of flavonoids, other phenolics, terpenoids, aliphatic acids, alcohols, and carbohydrates.

Retention indices were calculated from the results of the separation $\mathrm{C}_{8}-\mathrm{C}_{40} n$-alkane solutions in hexane and the TMS derivatives. The obtained $I^{T}$ values were compared with NIST collection (NIST 2013) as well as with the authors' previously published data (Isidorov et al. 2009, 2014a, b; Isidorov 2015). Identification was considered reliable if the results of a computer search in the mass spectra library were confirmed by the experimental $I^{T}$ values, i.e., if their deviation from the averaged literature values did not exceed $\pm 10 \mathrm{u}$. i. (inter-laboratorial deviation for low polar stationary phases).

\subsection{P. larvae strain isolation}

P. larvae were isolated from dead honey bee larvae and honey sample originating from apiaries in south-eastern Poland with AFB-diseased colonies (Isidorov et al. 2017). Briefly, dead larvae were aseptically removed from brood combs and then were crushed and suspended in $5 \mathrm{~mL}$ of physiological saline $(0.9 \% \mathrm{NaCl})$, and shook for $10 \mathrm{~min}$. To isolate bacteria from honey samples, $10 \mathrm{~mL}$ of honey was preheated to $45^{\circ} \mathrm{C}$, diluted with sterile water (a ratio of 1:1), and centrifuged at $3000 \times \mathrm{g}$ for $30 \mathrm{~min}$. The resulting pellets were suspended in $200 \mu \mathrm{L}$ of $0.9 \% \mathrm{NaCl}$. The suspensions of crashed larvae and honey were centrifuged at 10,000 rpm for $5 \mathrm{~min}$, and the resulting pellets were suspended in $900 \mu \mathrm{L}$ of $0.9 \% \mathrm{NaCl}$. All samples were preheated for $10 \mathrm{~min}$ at $85^{\circ} \mathrm{C}$ in order to eliminate vegetative cells and to select the endospores, spread on a Columbia Blood Agar Base supplemented with vitamin $\mathrm{B}_{1}$ (Oxoid, Basingstoke, England), and incubated at $30{ }^{\circ} \mathrm{C}$ in $5 \%$ of $\mathrm{CO}_{2}$ for $48-96 \mathrm{~h}$. Those Gram-positive bacteria forming round, transparent, or slightly whitish colonies with a diameter of about 2$3 \mathrm{~mm}$, catalase-negative, and creating spiral forms in the Plagemann probe were classified as P. larvae (Neuendorf et al. 2004; Plagemann 1985). The $P$. larvae strain LMG 09820 (Belgian Coordinated Collections of Microorganisms) was used as a control. 


\subsection{P. larvae strain ERIC genotyping}

According to Genersch et al. (2006), four ERIC (enterobacterial repetitive intergenic consensus) genotypes, ERIC I-IV, could be identified among P. larvae strains. However, only ERIC I and II are the practically important genotypes while ERIC III and IV have not been registered in field isolates and exist only in culture collections (Alippi et al. 2004; Antúnez et al. 2007; Genersch and Otten 2003). For ERIC genotyping, total DNA of the "wild" P. larvae strains under study was prepared from the 48-h cultures of the isolates grown in Mueller-Hinton broth (Oxoid) using a DNeasy Blood and Tissue Kit (Qiagen GmbH, Hilden, Germany) and the QIAcube apparatus (Qiagen) according to the manuals for Gram-positive bacteria. The DNA level and purity were checked using a NanoDrop 2000 spectrometer (Thermo Fisher Scientific Com., Waltham, USA).

ERIC genotyping was performed using primers designed previously (Versalovic et al. 1994). The PCR reactions were carried out with $1.5 \mathrm{U}$ Taq DNA polymerase (MBI Fermentas, Vilnius, Lithuania), $250 \mathrm{ng}$ of DNA, $0.5 \mathrm{mM}$ of each of the four dNTP, $1.5 \mathrm{mM} \mathrm{MgCl}_{2}$, and $1.0 \mu \mathrm{M}$ of each primer in a total volume of $25 \mu \mathrm{L}$. The PCR conditions were as follows: a single denaturation step at $94{ }^{\circ} \mathrm{C}$ for $5 \mathrm{~min}, 35$ cycles of denaturation of the DNA template at $95^{\circ} \mathrm{C}$ for $1 \mathrm{~min}$, annealing of primers at $57{ }^{\circ} \mathrm{C}$ for $1 \mathrm{~min}$, and extension of PCR products at $72{ }^{\circ} \mathrm{C}$ for $2.5 \mathrm{~min}$. An extra extension step was performed at $72{ }^{\circ} \mathrm{C}$ for $10 \mathrm{~min}$. Amplified products and two DNA markers, GeneRuler DNA Ladders 100 bp and GeneRuler DNA Laders 1 kb Thermo Fisher Scientific Co., were separated in a $1.2 \%$ agarose gel and stained with ethidium bromide $(0.5 \mu \mathrm{g} / \mathrm{mL})$. The gels were photographed under UV light using the ChemiDoc XRS+ System (Bio-Rad Laboratories, Hercules, USA). The PCR was prepared in triplicate.

\subsection{Antibacterial activity of plant extracts}

The prepared plant-derived extracts and selected chemicals (pure triterpenoids, flavonoids, and glucosides) were tested against wild $P$. larvae isolates, as well as against the reference strain
LMG 09820. The plant extracts and pure chemicals were dissolved in DMSO at concentration, respectively, of $10 \mathrm{mg} / \mathrm{mL}$ and $100 \mathrm{mM}$, sonicated in the Branson 2510 ultrasonic bath (Sigma), and filtrated with a $0.22-\mu \mathrm{m}$ pore size Rotilabo-Spritzenfilter filter (Carl Roth $\mathrm{GmbH}$ and Co, Karlsruhe, Germany). The bacterial strains kept at $-80^{\circ} \mathrm{C}$ were inoculated onto blood agar (Oxoid) and incubated for $48 \mathrm{~h}$ at $37{ }^{\circ} \mathrm{C}$. Then, bacteria were re-inoculated into MuellerHinton broth and incubated until the cultures reached an optical density of $0.2-0.3$ at $600 \mathrm{~nm}$, measured with a V-670 spectrophotometer (Jasco, Japan).

Firstly, the antimicrobial activity of the plant extracts against $P$. larvae isolates and the reference strain was investigated by the agar well diffusion test. Shortly, an overnight culture $(100 \mu \mathrm{L})$ of microorganism of $\mathrm{OD}_{600} \sim 0.2$ was carefully and evenly spread over Mueller-Hinton agar plates with a spreader, and then wells of $8 \mathrm{~mm}$ diameter were aseptically punched using a sterile cork borer. The bottom of the wells was filled with $15 \mu \mathrm{L}$ of preheated Mueller-Hinton agar to protect the extract against flowing under the agar. After the agar solidification, $80 \mu \mathrm{L}$ of each extract solution of concentration of 2,5 , and $10 \mathrm{mg} / \mathrm{mL}$ was pipetted into the wells and cultured for $48 \mathrm{~h}$ at $37^{\circ} \mathrm{C}$, followed by calculation of an average values from five diameters of the inhibited growth zones of $P$. larvae strains under study from five replications. The well diameters were included as the inhibition zone. Additionally, susceptibility of the $P$. larvae strains to antibiotics was tested, using commercial discs of tetracycline (30 $\mu \mathrm{g}$, Oxoid Ltd., Basingstoke, UK) and vancomycin $(30 \mu \mathrm{g})$, according to the producer's procedure and recommendation of the National Committee for Clinical Laboratory Standards (NCCLS).

Secondly, the antimicrobial activity of the plant extracts and selected chemicals was also assessed in the tube dilution assay, allowing the determination of the minimal inhibitory concentration (MIC). The MIC values were accomplished in accordance with (i) the Clinical and Laboratory Standard Institutes (2011) protocols and (ii) recommendation of Andrews (2001). The stocks of extract solutions $(2 \mathrm{mg} / \mathrm{mL})$ were aseptically 
diluted in double-concentrated Mueller-Hinton broth, receiving the arithmetic dilution series ranging from 0.5 to $1000 \mu \mathrm{g} / \mathrm{mL}$ in final volumes of $3 \mathrm{~mL}$. Similarly, the stock solutions of tested chemicals were used for serial dilution from 0.0015 to $25 \mathrm{mM}$. Then, $30 \mu \mathrm{L}$ of the bacterial culture of $\mathrm{OD}_{600} \sim 0.2$ was added to each tube with the extracts or chemical solutions. The bacteria were incubated for $48 \mathrm{~h}$ at $37{ }^{\circ} \mathrm{C}$. The lowest concentration of the plant extracts which there was no visible growth was taken as the MIC. All the tests were repeated four times. The same procedure was also used to test the growth inhibition of tylosin (Sigma-Aldrich). In our experiment, the concentration of tylosin ranged from 0.001 to $500 \mu \mathrm{g} / \mathrm{mL}$. This antibiotic is approved to use against $P$. larvae in the field (Wilson et al. 2015).

In both, the agar well diffusion test and the tube dilution assay (MIC determination), for the control $P$. larvae grown in Mueller-Hinton media (Mueller-Hinton agar in the agar well diffusion test or Mueller-Hinton broth in the MIC test) neither with the plant extracts nor with chemicals were chosen as positive controls. The media without bacteria incubated at the same conditions as the tested cultures were considered as negative controls. $P$. larvae strains growing onto/into media supplemented with $10 \%$ DSMO were used as a solvent control. Similar growth of the bacteria under study in Mueller-Hinton medium without DMSO and in Mueller-Hinton medium supplemented with $10 \%$ DMSO was observed in both tests, which allowed us to conclude that DMSO itself does not affect the P. larvae growth.

\subsection{Statistical methods}

The means and standard deviations (SD) were applied in descriptive statistics for continuous variables. To assess differences in antibacterial activity of plant extracts on $P$. larvae strains, two-way ANOVA analyses were performed, with diameter of zone of inhibition as an explained variable, and P. larvae strain and extract concentration as explanatory variables; $p$ values were reported. Whereas to compare antibacterial activity between plant extracts on each of $P$. larvae strains, two-way ANOVA analyses were performed, with diameter of zone of inhibition as an explained variable, and plant extract and extract concentration as explanatory variables; $p$ values were reported.

To assess effect of extract concentration on diameter of zone of inhibition, randomintercept mixed model was developed, with fixed effects for an extract-concentration interaction. Estimated coefficients with $95 \%$ confidence intervals and $p$ values from the distribution were reported. The significance level was set at 0.05 . Analysis was performed with $\mathrm{R}$ statistical software, version 3.4.0 (R Core Team (2017).

\section{RESULTS}

\subsection{ERIC classification of the P. larvae isolates used in this study}

The DNA pattern of the $P$. larvae isolates KB25, KB35, KB41, KB55, and the reference strain (LMG 09820) obtained by PCR with the ERIC primers showed identical ERIC patterns regardless of the origin of the samples from which they were isolated (Figure 1). Based on comparison between the obtained DNA fingerprints and those published previously (Genersch and Otten 2003; Genersch et al. 2006), the isolates were classified as the ERIC I genotype.

\subsection{Chemical composition of extracts}

In this work, the action on $P$. larvae of extracts from buds and young-leaved twigs of resin-giving plants (downy and silver birch, black poplar, and common aspen) of the boreal and temperate zones of Europe (Isidorov et al. 2016) was investigated. In different extracts of buds and young twigs, more than 390 organic compounds were registered by GC-MS with the relative content not less than $0.01 \%$ of TIC. For this reason, Table I gives only the group composition of extracts and the relative content of representatives of these groups.

The chemical composition of the diethyl ether extracts of ground buds (samples Bd-1-Bd-6) was rather close to the composition of previously investigated resins covering buds of corresponding 


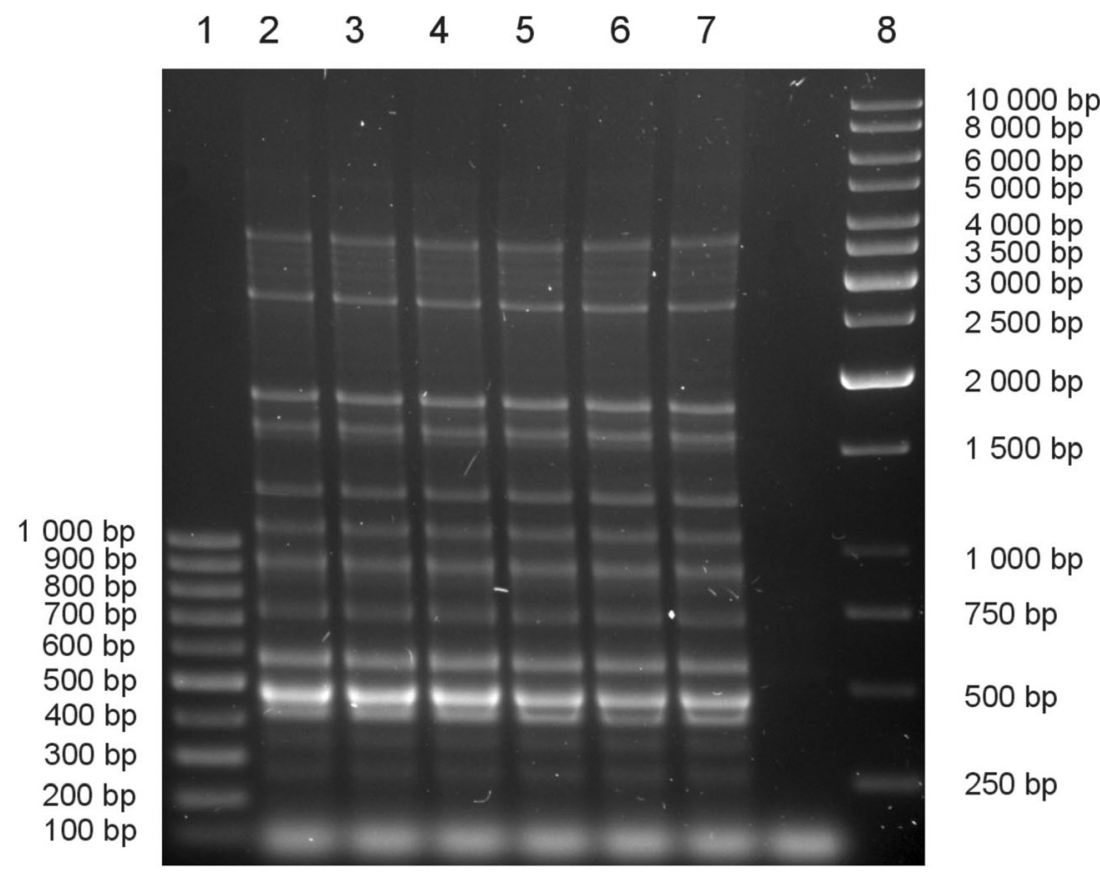

Figure 1 ERIC I patterns of $P$. larvae strains used in the study. Line: 1, GeneRuler DNA Ladders 100 bp (Thermo Fisher Scientific Com.); 2 and 7, LMG 09820; 3, KB25; 4, KB35; 5, KB41; 6, KB55; 8, GeneRuler DNA Ladders $1 \mathrm{~kb}$ (Thermo Fisher Scientific Com.).

trees: two species of birch, black poplar, and aspen (Isidorov and Vinogorova 2003; Isidorov et al. 2014a, b, 2016). However, some differences were observed at both qualitative and quantitative levels. For example, extracts Bd-3, Bd-5, and Bd-6 from ground silver birch and aspen buds contained a noticeable quantity (10-12\% of TIC) of flavonoids (Table I) while their content in diethyl ether extract of resin covering silver birch and aspen bud surfaces was 0.9 and $4.2 \%$, respectively (Isidorov et al. 2014b). Another difference concerns the content of catechin in extracts. Substantial quantities of this flavan-3-ol were detected in the extracts from ground buds of birches, poplar, and aspen (Table I); however, it was absent in the bud exudates collected by honey bees in the temperate zone of Europe (Isidorov et al. 2016).

Young twigs of two birch species were extracted successive with solvents of different polarity: non-polar $n$-hexane, poorly polar diethyl ether, and highly polar methanol. For this reason, the chemical composition of extracts was very different. The main components of the hexane extracts of both birch species were formed by relative poorly polar $\mathrm{C}_{30} \mathrm{H}_{48} \mathrm{O}, \mathrm{C}_{30} \mathrm{H}_{50} \mathrm{O}, \mathrm{C}_{30} \mathrm{H}_{52} \mathrm{O}_{2}$, and $\mathrm{C}_{30} \mathrm{H}_{50} \mathrm{O}_{3}$ triterpenoids. Although lupane series triterpenoids such as lupeol, betulinol, betulinic acid, and, related to latter, oleanolic acid are characteristic for both white birch species, representatives of dammarane series terpenoids (dammaradien-3-one and dipterocarpol) were only detected in extracts of silver birch. More contrasting is the chemical composition of the diethyl ether extracts of twigs. Downy birch extract contained $36.4 \%$ flavonoids, the content of which in silver birch extract was very low $(0.3 \%)$. Different to the former species, the latter contained only trace amounts of sesquiterpenoids but large amounts of triterpenoids (60\%).

Species-specific differences were also observed in the composition of glucosides, the most polar components extracted from birch twigs by methanol. In accordance with literature data (Laitinen et al. 2005), silver birch twigs contained a large amount of platyphylloside, (5S)-5-hydroxy-1,7-bis-(4-hydroxyphenyl)-3-heptanone-5O- $\beta$-D-glucopyranoside, which was completely absent in downy birch. In turn, specific to downy 


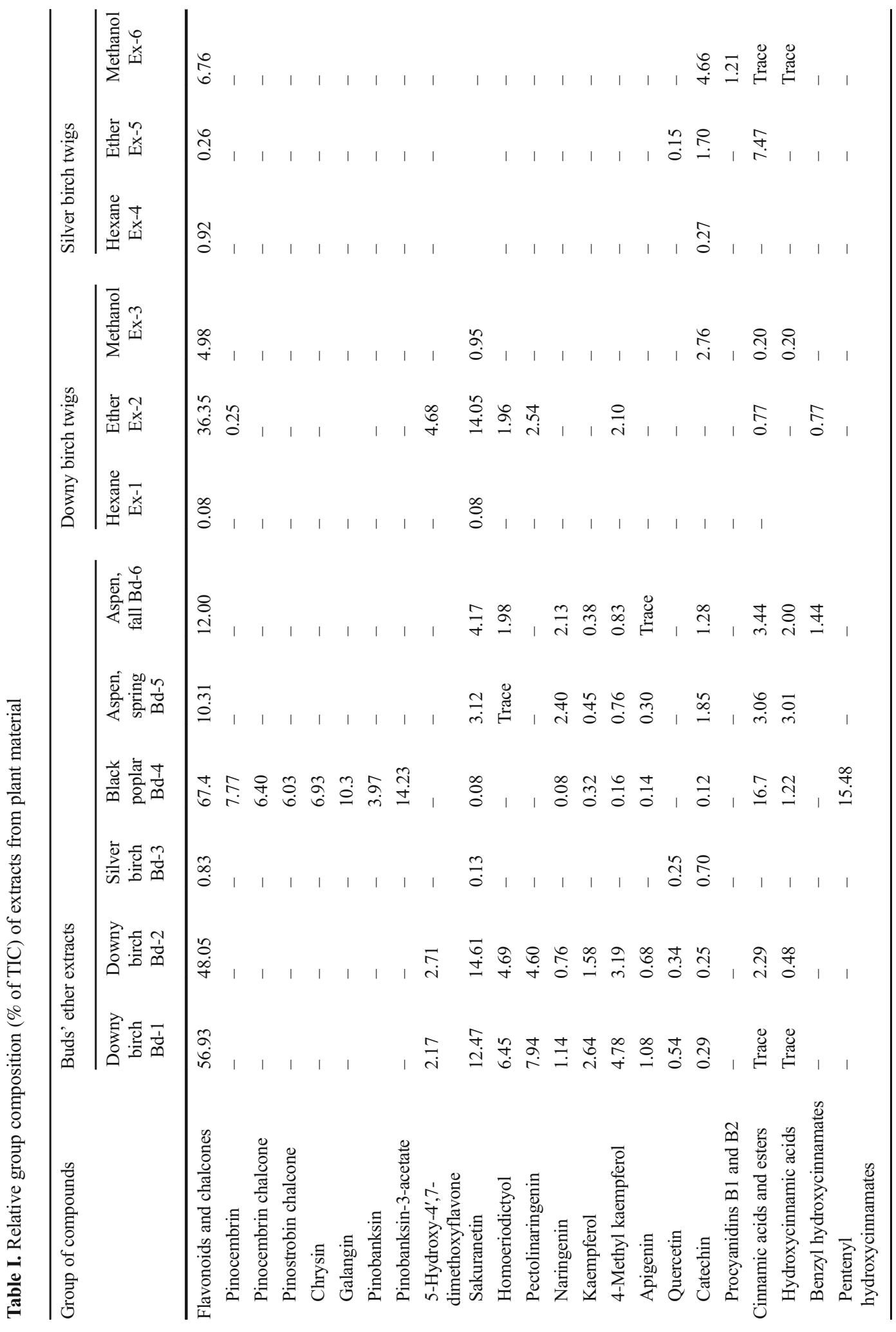




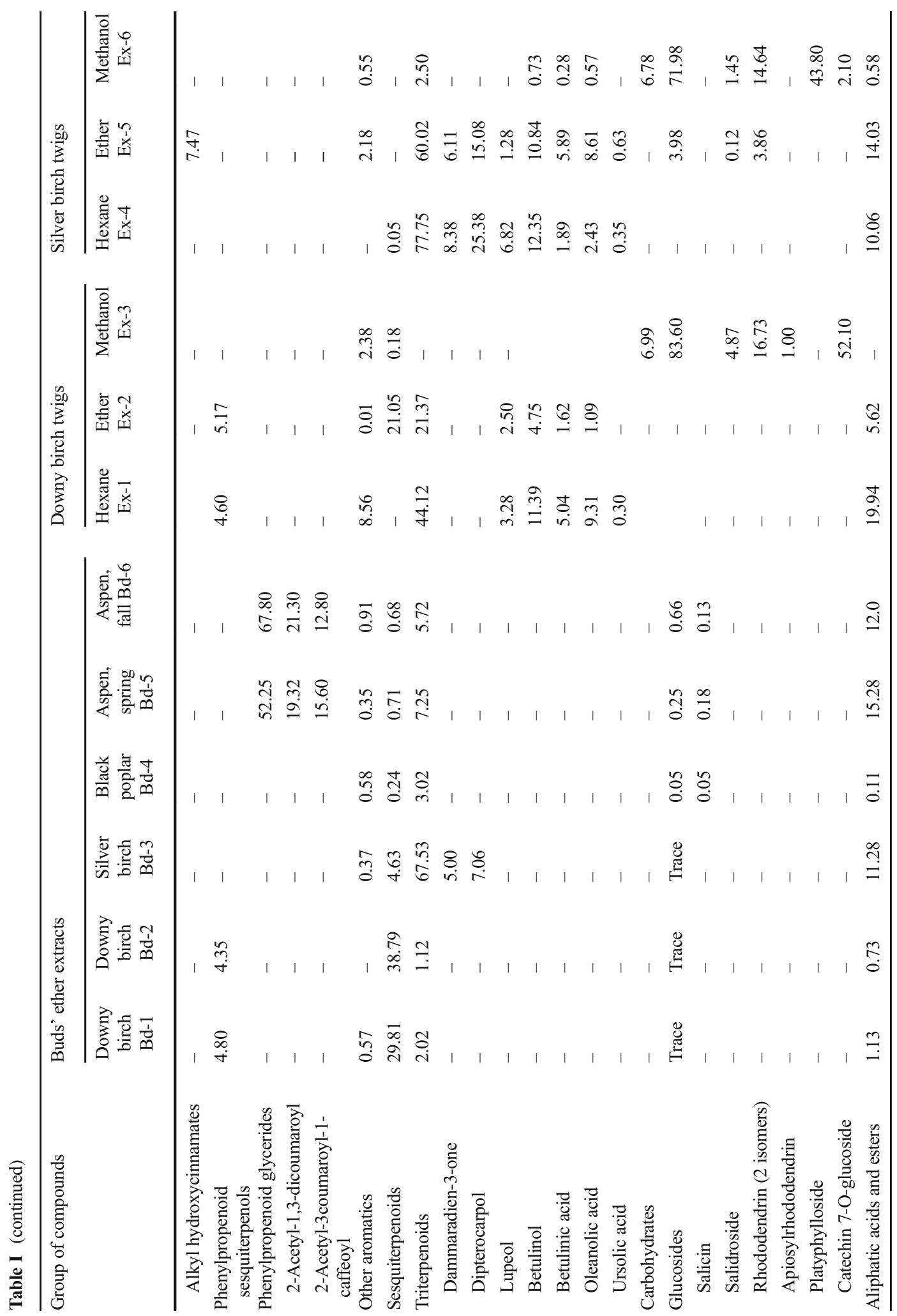


birch glucoside was apiosylrhododendrin (Santamour and Lundgren 1997). However, the main glucoside in the methanol extract of downy birch was catechine-7-O-D-glucopyranoside. To the best of our knowledge, it has not previously been identified in white birch tissue. Other highly polar components of methanol extracts from birch twigs were represented by catechin and its dimers, procyanidins B1 and B2.

\subsection{Antibacterial activity}

For testing the antibacterial activity of plant extracts, we used an agar well diffusion test and a tube dilution assay. As given in Table II, the highest anti- $P$. larvae activity was noted for bud extracts from $B$. pendula (Bd-3) and P. nigra (Bd-4). For these extracts at the concentration of $10 \mathrm{mg} / \mathrm{mL}$, the inhibition zones varied from 27.2 $\pm 0.7 \mathrm{~mm}$ (KB25) to $30.5 \pm 0.5 \mathrm{~mm}$ (KB55 and LMG 09820), and from $25.7 \pm 0.9 \mathrm{~mm}$ (LMG 09820 ) to $30.2 \pm 0.4 \mathrm{~mm}$ (KB25 for the B. pendula (Bd-3) and P. nigra (Bd-4) extracts), respectively. Among birch twig extracts, the highest activity was observed for hexane extracts from $B$. pubescens (the inhibition zones from $23.0 \pm 0.6$ to $30.4 \pm 0.5 \mathrm{~mm}$ for $\mathrm{KB} 55$ and KB41, respectively) and hexane extracts from the $B$. pendula twigs (the inhibition zones from $28.0 \pm 0.0$ to $30.8 \pm 1.2 \mathrm{~mm}$ for KB55 and LMG 09820, respectively). As presented in Table II, we found statistically significant differences in antibacterial effect of Bd-1, Bd-3, Bd-5, Ex-2, Ex-3, and Ex-5 between $P$. larvae strains (two-way ANOVA $p$ value for $P$. larvae strains $<0.001$ in each test), while antibacterial effect of Bd-4, Ex-1, and Ex-4 did not differ significantly between $P$. larvae strains. We also found statistically significant differences in antibacterial activity between extracts on each of $P$. larvae strain (twoway ANOVA $p$ value for extract $<0.001$ in each test). All $P$. larvae isolates under study and the reference strain LMG 09820 were susceptible to vancomycin and tetracycline, with the inhibition zones ranging from $25.7 \pm 0.2$ to $26.1 \pm 0.1 \mathrm{~mm}$ for vancomycin and being $>40 \mathrm{~mm}$ for tetracycline (Table II).

Effect of extract concentration on diameter of zone of inhibition estimated in mixed model was 
V. A. Isidorov et al.

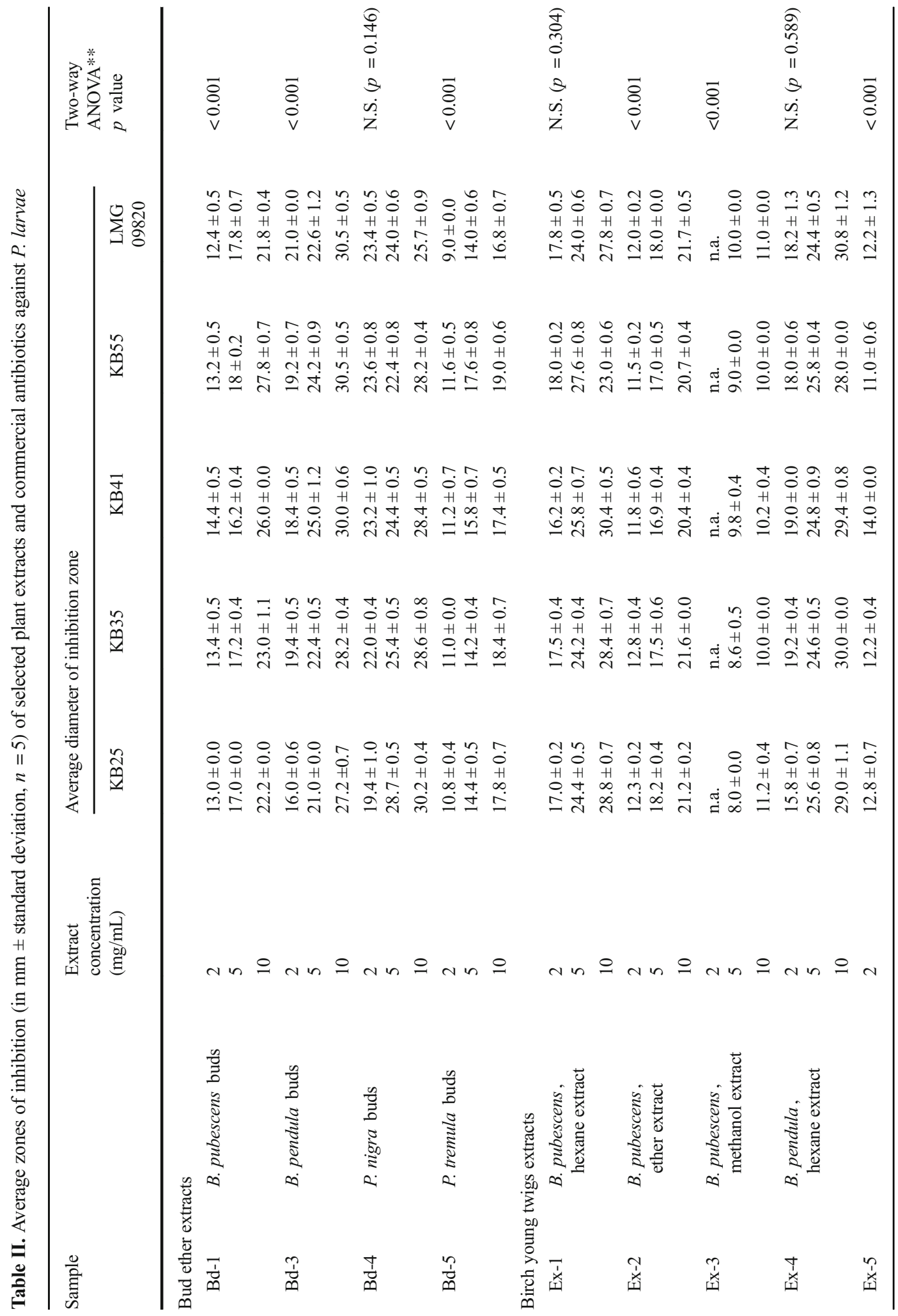




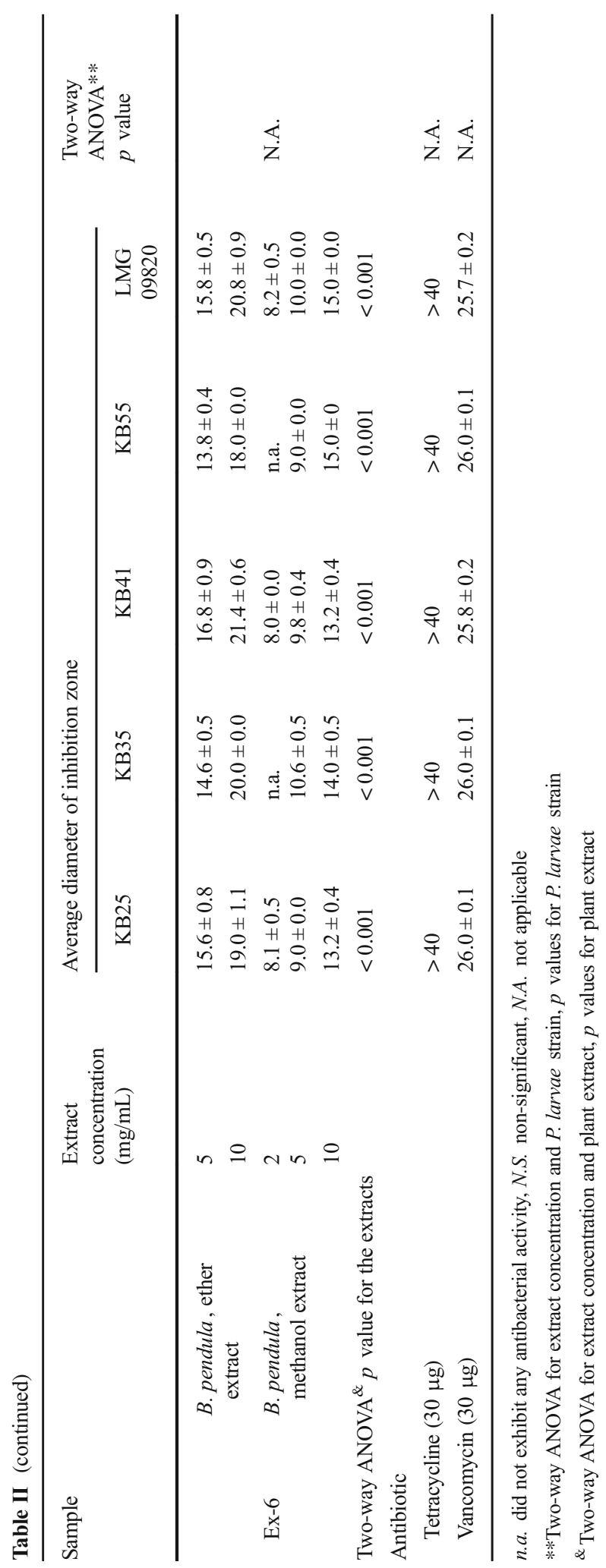


Table III. Effect of selected plant extract concentration on diameter of zone of inhibition ( $\mathrm{mm}$ ) in mixed model fixed effects estimates

\begin{tabular}{|c|c|c|c|}
\hline Variable* & Coefficient & $95 \% \mathrm{CI}$ & $p$ value \\
\hline (Intercept) & 13.964 & $13.417-14.510$ & $<0.001$ \\
\hline Bd-1 & 0.879 & $0.767-0.991$ & $<0.001$ \\
\hline $\mathrm{Bd}-3$ & 1.564 & $1.453-1.676$ & $<0.001$ \\
\hline $\mathrm{Bd}-4$ & 1.666 & $1.554-1.778$ & $<0.001$ \\
\hline Bd-5 & 0.098 & $-0.014-0.209$ & 0.088 \\
\hline Ex-1 & 1.540 & $1.428-1.652$ & $<0.001$ \\
\hline Ex-2 & 0.815 & $0.703-0.927$ & $<0.001$ \\
\hline Ex-3 & -0.464 & -0.575 to -0.354 & $<0.001$ \\
\hline Ex-4 & 1.489 & $1.377-1.601$ & $<0.001$ \\
\hline Ex-5 & 0.629 & $0.517-0.741$ & $<0.001$ \\
\hline
\end{tabular}

*Plant extract concentrations (in $\mathrm{mg} / \mathrm{mL}$ ) were used as a variable

significantly higher than zero for extracts $\mathrm{Bd}-1$, Bd-3, Bd-4, Ex-1, Ex-1, Ex-4, and Ex-5. The greatest effect was observed for Bd-3, Bd-4, Ex1, and Ex-4, for which the concentration increase of $1 \mathrm{mg} / \mathrm{mL}$ results in the increase in inhibition zone by about $1.5 \mathrm{~mm}$. The results on the effect of extract concentration on diameter of zone of inhibition estimated in mixed model are given in Table III.

In the tube dilution assay, we determined the sensitivity of the wild isolates as well as the reference $P$. larvae strain LMG 09820 shown as the

Table IV. Minimal inhibitory concentration (MIC) of different extracts and tylosin for Paenibacillus larvae strains used in the study

\begin{tabular}{|c|c|c|c|c|c|c|}
\hline \multirow[t]{2}{*}{ Sample } & & \multicolumn{5}{|c|}{$\mathrm{MIC}(\mu \mathrm{g} / \mathrm{mL})$ for $P$. larvae } \\
\hline & & KB25 & KB35 & KB41 & KB55 & LMG 09802 \\
\hline \multicolumn{7}{|c|}{ Bud ether extracts } \\
\hline Bd-1 & B. pubescens buds (IV.2015) & 7.8 & 7.8 & 7.8 & 7.8 & 15.6 \\
\hline $\mathrm{Bd}-2$ & B. pubescens buds (IX.2015) & 7.8 & 7.8 & 7.8 & 7.8 & 15.6 \\
\hline Bd-3 & B. pendula buds (IX.2015) & 1.95 & $<1.0$ & $<1.0$ & 3.9 & $<1.0$ \\
\hline $\mathrm{Bd}-4$ & P. nigra buds (IX.2015) & 7.8 & 7.8 & 7.8 & 15.6 & 7.81 \\
\hline $\mathrm{Bd}-5$ & P. tremula buds (IV.2015) & 31.8 & 15.6 & 15.6 & 15.6 & 15.6 \\
\hline Bd-6 & P. tremula buds (IX.2015) & 31.8 & 15.6 & 15.6 & 15.6 & 15.6 \\
\hline \multicolumn{7}{|c|}{ Birch twigs extracts } \\
\hline Ex-1 & B. pubescens, hexane extract & 3.9 & 3.9 & $<1.0$ & $<1.0$ & 7.8 \\
\hline Ex-2 & B. pubescens, ether extract & 15.6 & 15.6 & 31.8 & 31.8 & 7.8 \\
\hline Ex-2 & B. pubescens, methanol extract & 62.5 & 62.5 & 125.0 & 125.0 & 62.5 \\
\hline Ex-3 & B. pendula young twigs, hexane extract & $<1.0$ & $<1.0$ & $<1.0$ & 3.9 & $<1.0$ \\
\hline Ex-4 & B. pendula young twigs, methanol extract & 31.8 & 31.8 & 31.8 & 15.6 & 7.8 \\
\hline Ex-5 & B. pendula, ether extract & 31.8 & 31.8 & 31.8 & 15.6 & 7.8 \\
\hline Ex-6 & B. pendula, methanol extract & 31.8 & 31.8 & 62.5 & 62.5 & 62.5 \\
\hline Tylosin & & $<1.0$ & $<1.0$ & $<1.0$ & $<1.0$ & $<1.0$ \\
\hline
\end{tabular}


Table V. Minimal inhibitory concentration of selected plant derived compounds for Paenibacillus larvae MIC $(\mu \mathrm{g} / \mathrm{mL})$ for $P$. larvae strains

$\begin{array}{llllllll}\text { Triterpenoid } & \text { Formula } & \text { MW } & \text { KB25 } & \text { KB35 } & \text { KB41 } & \text { KB55 } & \text { 09820 }\end{array}$

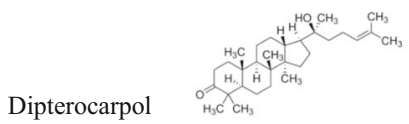

Lupeol

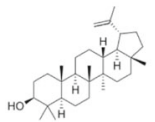

Betulin

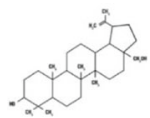

Betulinic acid

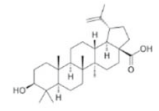

Ursolic acid
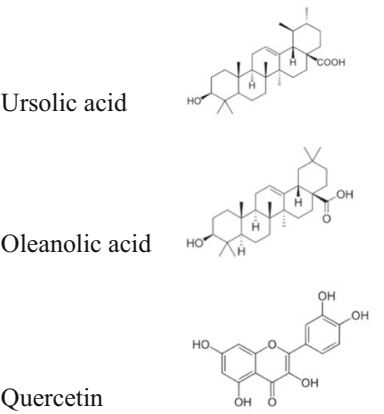

Quercetin

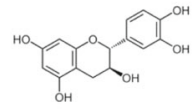

(+)-Catechin

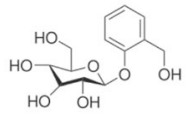

Salicin

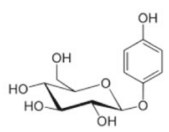

Arbutin

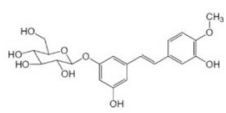

Rhaponticin

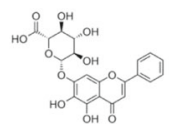

$442.7 \quad 34.5$

34.5

17.3

$426.7 \quad 33.3$

8.5

$8.55 \quad 16.6$

4.3

$442.7 \quad 69.1$

17.3

17.3

$17.3<4.4$

\begin{tabular}{ll}
$456.7 \quad 9.1$ \\
\hline
\end{tabular}

18.3

9.1

4.6

9.11

$456.7 \quad 17.8$

17.8

17.819

$<4.6$

$456.7 \quad 35.6$

17.8

17.8

35.6

$<4.6$

$302.3 \quad 295.0$

$290.3 \quad 1814.02 \quad-$

$272.2>10000$

$>10000$

$268.3 \quad 7157.5$

$>10000$

$$
\text { *- not tested }
$$

*-not tested
Baicalin

Baicalin
*-not tested


MIC value for each extract used in the study. The results are presented in Table IV. In spite of the great differences in the chemical composition, all tested extracts significantly inhibited the growth of $P$. larvae, with MIC from < 1 to $125 \mu \mathrm{g} / \mathrm{mL}$. The most active was the ether extract from silver birch buds, as well as the $n$-hexane extracts of silver and downy birch twigs, which showed MIC values from below 1.0 to $3.9 \mu \mathrm{g} / \mathrm{mL}$. Significantly lower anti-P. larvae activity was demonstrated in methanol extracts, with MIC values from 31.8 to $125 \mu \mathrm{g} / \mathrm{mL}$. In the agar well diffusion test, the antimicrobial activity of the extracts was confirmed. The MIC value for tylosin was assessed to be lower than $1 \mu \mathrm{g} / \mathrm{mL}$ (Table IV).

To examine the causes of observed differences in anti- $P$. larvae activity, the antimicrobial properties of selected pure chemicals (triterpenoids, flavonoids, and glycosides) were determined (Table V). The most potent anti-P. larvae compounds were triterpenoids while the flavonoids and glucosides tested demonstrated considerably weaker activity (quercetin, catechin, baicalin) or were entirely inactive (salicin, arbutin, rhaponticin).

\section{DISCUSSION}

The isolates KB25, KB35, KB41, and KB55 used in this study were previously classified as P. larvae (Isidorov et al. 2017) based on the colony shape (round, slightly whitish), lack of catalase, formation of spiral forms in the Plagemann test, and the 16S RNA sequences (Neuendorf et al. 2004; Plagemann 1985). In this study, we determined that all of them belong to the ERIC I genotype. According to Genersch (2010), ERIC I and ERIC II are the two most important genotypes of $P$. larvae which can be isolated from AFB-diseased colonies in Europe. These two genotypes differ in their ability to cause disease at the larval stage. ERIC I and ERIC II needed 12 and 7 days, respectively, to kill all infected larvae. Hence, larvae infected by the fast-killing genotype ERIC II die for the most part before cell capping and can be removed (prior to production of infectious spores) by nurse bees as part of the social immune defense (Spivak and Reuter 2001; Genersch 2010). Removal of capped dead prepupae killed by ERIC I, as well as those containing huge amount of spores in a ropy mass from cell bottom, is less efficient and can favor disease transmission within a colony. For this reason, the majority of AFB cases registered in Poland are probably caused by the slower killing P. larvae ERIC I genotype.

The results of microbiological assays presented in Tables II, III, and IV allow us to draw some preliminary conclusions. The first consists of stating the high efficiency of extracts from buds of resin-giving plants against $P$. larvae. In principle, the high antimicrobial activity of these extracts may not be surprising because their chemical composition is very close to the composition of honey bee propolis. The antimicrobial activity of honey bee products such as propolis and honey is attributed to flavonoids and phenylcarboxylic and hydrocinnamic acids: the higher the content of these phenolic compounds, the stronger the antibiotic properties of propolis or honey (Burdock 1998; Chen et al. 2018; Hegazi et al. 2000; Da Silva Filho et al. 2008; Kujumgiev et al. 1999; Popova et al. 2017; Wilson et al. 2017). In accordance with this conception is the observation of higher anti$P$. larvae activity of extracts from $B$. pubescens and $P$. nigra buds compared to the activity of $P$. tremula bud extracts: the latter contains about five times less flavonoids (Table I). However, the highest activity against $P$. larvae was demonstrated by the extract from $B$. pendula buds with a relative small concentration (10.5\% of TIC) of flavonoids. The principal components of this material (ca. $68 \%$ of TIC) are very complex and difficult to identify mixture of relatively poorly polar triterpenoids. Hence, the second conclusion is that the anti$P$. larvae activity of the investigated plant extracts is connected in a certain way with the polarity of their constituents.

This hypothesis agrees with the MIC values presented in the second part of Table IV. It can be seen that the ether extract of downy birch twigs (Ex-2), with a relatively high content of flavonoids (36.5\% of TIC), demonstrated lower anti$P$. larvae activity than the hexane extract Ex-1 which contained only trace amounts of flavonoids. However, the tested $P$. larvae isolates were most susceptible to (nearly deprived of phenolics) the hexane extract from silver birch twigs (Ex-4). On the other hand, methanol extracts from downy 
birch (Ex-3) and silver birch twigs (Ex-6) were substantially less active than both hexane extracts. Diethyl ether extracts Ex-2 and Ex-4 demonstrated intermediate activity.

The chemical composition of these three groups of extracts was highly contrasting. Highly polar methanol extracts from twigs contain highly polar hydrophilic compounds: carbohydrates and glucosides (Abyshev et al. 2007; Julkunen-Tiitto et al. 1996), while the poorly polar ether and nonpolar $n$-hexane extract less polar and relatively lipophilic methoxylated flavonoids (sakuranetin, homoeriodictyol, pectolinaringenin, 4methylkaempherol) and triterpenoids.

It is interesting to note that Boligon et al. (2013) evaluated the effect of crude extract and fractions of Scutia buxifolia against six Paenibacillus species, including P. larvae. It was found that the non-polar dichloromethane fraction showed the best MIC value $(1.56 \mathrm{mg} / \mathrm{mL})$, followed by moderately polar ethyl acetate $(6.25 \mathrm{mg} / \mathrm{mL})$ and polar $n$-butanol fractions $(25.0 \mathrm{mg} / \mathrm{mL})$. Kujumgiev et al. (1999) also noted that a decrease of the polar phenolic compound content in propolis was not accompanied by a decrease of activity against Staphylococcus aureus. The authors speculated that triterpenes, making up about $18 \%$ of the "balsam" of Egyptian propolis, might play a role in its antimicrobial properties. In a very recent study, Wilson et al. (2017) have isolated from American propolis 11 structurally related 3-acylpinobanksins (dihydroflavonols with non-substituted B ring) and characterized their anti- $P$. larvae activity. The antimicrobial action was related to acyl group length where less polar compounds (with longer acyl group) were better inhibitors of $P$. larvae. All these findings are consistent with our observation of anti-P. larvae action of investigated plant extracts.

In order to examine the relationship between the polarity of different compounds and their antiP. larvae activity, we determined the MIC values of selected triterpenoids, flavonoids, and glucosides (Table V). These experimental data demonstrate for the first time the high activity against anti-P. larvae of triterpene alcohols and acids, but the lower activity of more polar flavonoids and, especially, highly polar glucosides. It is remarkable that baicalin containing a hydrophobic fragment in its molecule (non-substituted B ring) was much active than other glucosides. It can be assumed that high lipophilicity enables them to partition the lipids of the bacterial cell membrane and/or connect with the hydrophobic parts of proteins embedded in the cytoplasmic membrane, disturbing their structures (Burt 2004; Sikkema et al. 1995).

\section{CONCLUSION}

Antibiotics in the bee keeping are legally banned in many countries and this calls for an alternative control of AFB that do not contribute for the $P$. larvae resistance. Our study demonstrates that some plant extracts and plant-derived compounds (such as triterpenoids) have a high potential to control growth of these bacteria. The subsequent experiments will be devoted to oral toxicity of the more promising extracts to adult worker honey bees and field efficacy of administration.

\section{AUTHOR CONTRIBUTIONS}

VI-plant material collection, sample preparation, and GC-MS analysis; $\mathrm{KB}-P$. larvae isolation and characterization; AS - statistical analysis; GZ and IS - microbiological investigationsFunding information

The project was supported by Grant of National Science Center (Poland) 2014/13/B/NZ7/02280 and partly by the University of Bialystok (Project No. BST-107).

\section{OPEN ACCESS}

This article is distributed under the terms of the Creative Commons Attribution 4.0 International License (http://creativecommons.org/licenses/by/4.0/), which permits unrestricted use, distribution, and reproduction in any medium, provided you give appropriate credit to the original author(s) and the source, provide a link to the Creative Commons license, and indicate if changes were made.

Activité d'extraits de plantes sélectionnés contre l'agent pathogène de l'abeille mellifère Paenibacillus larvae 
Abeille domestique / Paenibacillus larvae / extraits de plantes / activité antimicrobienne

\section{Aktivität bestimmter Pflanzenextrakte gegen das Honigbienenpathogen Paenibacillus larvae}

\author{
Honigbiene / Paenibacillus larvae / Pflanzenextrakte / \\ antimikrobiale Aktivität
}

\section{REFERENCES}

Abyshev, A.Z., Agaev, E.M., Guseinov, A.B. (2007) Studies of the chemical composition of birch bark extracts (Cortex betula) from the Betulaceae family. Pharm. Chem. J. 41, 419-423

Albo, G.H., Henning, C., Ringuelter, F.J., De Giusti, M.R., Alippi, A.M. (2003) Evaluation of some essential oils for the control and prevention of American Foulbrood disease in honey bees. Apidologie 34, 417-427

Alippi, A.M., Ringuelet, J.A., Cerimele, E.L., Re, M.S., Henning, C.P. (1996) Antimicrobial activity of some essential oils against Paenibacillus larvae, the causal agent of American foulbrood disease. J. Herbs Spices Med. Plants 4, 9-12

Alippi, A.M., Reynaldi, F.J., Lopez, A.C., De Giusti, M.R., Aguilar, O.M. (2004) Molecular epidemiology of Paenibacillus larvae and incidence of American foulbrood in Argentinian honeys from Buenos Aires province. J. Apicult. Res. 43, 135-143

Alonso-Salces, R.M., Cugneta, N.M., Guapari, E., Pellegrini, M.C., Aubone, J., de Piano, F.G., Antues, K., Fuselli, R. (2017) Natural strategies for control of Paenibacillus larvae, the causal agent of American foulbrood in honey bees: a review. Apidologie 48, 387-400

Andrews, J.M. (2001) Determination of minimum inhibitory concentrations. J. Antimicrob. Chemother. 48 (suppl_1), 5-16

Antúnez, K., Picinni, C., Castro-Sowinski, S., Rosado, A.S., Seldin, L., Zunino, P. (2007) Phenotypic and genotypic characterization of Paenibacillus larvae isolates. Vet. Microbiol. 124, 178-183

Antúnez, K., Harriet, J., Gende, L., Maggi, M., Eguaras, M., Zunino, P. (2008) Efficacy of natural propolis extract in the control of American Foulbrood. Vet. Microbiol. 131, 324-331

Bankova, V., Popova, M., Trusheva, B. (2006) Plant sources of propolis: an update from a chemist's point of view. Nat. Prod. Commun. 1, 1023-1028

Bastos, E.M.A.F., Simone, M., Jorge, D.M., Soares, A.E.E., Spivak, M. (2008) In vitro study of antimicrobial activity of Brazilian propolis against Paenibacillus larvae. J. Invertebr. Pathol. 97, 273-281

Bilikova, K., Popova, M., Trusheva, B., Bankova, V. (2013) New anti-Paenibacillus larvae substances purified from propolis. Apidologie 44, 278-285
Boligon, A.A., de Brum, T.F., Zandra, M., Piana, M., dos Santos Alves, C.F., Fausto, V.P., dos Santos Barboza, V., de Almeida Vaucher, R., Jr., Santos, R.C.V., Athayde, M.L. (2013) Antimicrobial activity of Scutia buxifolia against the honeybee pathogen Paenibacillus larvae. J. Invertebr. Pathol. 112, 105-107

Borba, R.S., Klyczek, K.K., Mogen, K.L., Spivak, M. (2015) Seasonal benefits of a natural propolis envelope to honey bee immunity and colony health. J. Exp. Biol. 218, 3689-3699, https://doi.org/10.1242/jeb.127324

Burdock, G.A. (1998). Review of the biological properties and toxicity of bee propolis (propolis). Food Chem. Toxicol. 36, 347-363

Burt, S. (2004). Essential oils: their antibacterial properties and potential application in food $\mathrm{s}-\mathrm{a}$ review. Int.. J. Food Microbiol. 94, 22-3253

Chaimanee, V., Thongtue, U., Sornmai, N., Songsri, S., Pettis, J.S. (2017) Antimicrobial activity of plant extracts against the honeybee pathogens, Paenibacillus larvae and Ascosphaera apis and their topical toxicity to Apis mellifera adults. J. Appl. Microbiol. 123, 1160-1167

Chen, Y.-W., Ye, S.-R., Ting, C., Yu, Y.H. (2018) Antibacterial activity of propolins from Taiwanese green propolis. J. Food Drug Anal. 26, 761-768

Clinical and Laboratory Standard Institute (2011) Performance standards for antimicrobial susceptibility testing. Twenty-first international supplement. M100-S21, Vol. 31, No 1, CLSI, Wayne, PA, USA

Da Silva Filho, A.A., de Sousa, J.P.B., Soares, S., Furtado, N.A.J.C., Andrade e Silva, M.L., Cunha, W.R.C., Gregório, L.E., Nanayakkara, N.P.D., Bastos, J.K. (2008) Antimicrobial activity of the extract and isolated compounds from Baccharis dracunculifolia D. C. (Asteraceae). Z. Naturforsch. 63c, 40-46

Evans, J.D., Schwartz, R.S. (2011) Bees brought to their knees: microbes affecting honey bee health. Trends Microbiol. 19, 614-620

Flesar, J., Havlik, J., Kloucek, P., Rada, V., Titera, D., Bednar, M., Stropnicki, M., Kokoska, L. (2010) In vitro growth-inhibitory effect of plant-derived extracts and compounds against Paenibacillus larvae and their acute oral toxicity to adult honey bees. Vet. Microbiol. 145, 129-133

Fuselli, S.R., de la Rosa, S.B.G., Gende, L.B., Eguaras, M.J., Fritz, R. (2006) Antimicrobial activity of some Argentinean wild plant essential oils against Paenibacillus larvae, causal agent of American foulbrood (AFB). J. Apicult. Res. 45, 2-7

Fuselli, S.R., de la Rosa, S.B.G., Eguaras, M.J., Fritz, R. (2008) Chemical composition and antimicrobial activity of citrus essences on honeybee bacterial pathogen Paenibacillus larvae, the causal agent of American foulbrood. World J. Microbiol Biotechnol. 24, 2067-2072

Gende, L.B., Maggi, M.D., Fritz, R., Eguaras, M.J., Bailac, P.N., Ponzi, M.I. (2009) Antimicrobial activity of Pimpinella anisum and Foeniculum vulgare essential oils against Paenibacillus larvae subsp. larvae. J. Essent. Oil Res. 21, 91-93 
Gende, L.B., Fernándes, N., Buffa, F., Ruiu, L., Satta, A., Fritz, R., Eguaras, M.J., Floris, I. (2010) Susceptibility of Paenibacillus larvae isolates to tetracycline hydrochloride and cinnamon (Cinnamomum zeylanicum) essential oil mixture. Bull. Insectol. 63, 247-250

Genersch, E. (2010) American Foulbrood in honey bees and its causative agent, Paenibacillus larvae. J. Invertebr. Pathol. 103, S10-S19

Genersch, E., Otten, C. (2003) The use of repetitive element PCR fingerprinting (rep-PCR) for genetic subtyping of German field isolates of Paenibacillus larvae subsp. larvae. Apidologie 34, 195-206

Genersch, E., Forsgren, E., Pentikäinen, J., Ashiralieva, A., Rauch, S., Kilwinski, J., Fries, I. (2006) Reclassification of Paenibacillus larvae subsp. pulvifaciens and Paenibacillus larvae subsp. larvae as Paenibacillus larvae without subspecies differentiation. Int. J. System. Evol. Microbiol. 56, 501-511

González, M.J., Marioli, J.M. (2010) Antibacterial activity of water extracts and essential oils of various aromatic plants against Paenibacillus larvae, the causative agent of American Foulbrood. J. Invertebr. Pathol. 104, 209-213

Hegazi, A.G., Hady, F.K.A.E., Allah, F.A.M.A. (2000) Chemical composition and antimicrobial activity of European propolis. Z. Naturforsch. 55c, 70-75

Isidorov, V.A., and Vinogorova, V.T. (2003) GC-MS analysis of compounds extracted from buds of Populus balsamifera and Populus nigra. Z. Naturforsch. 58c, 3553-3560

Isidorov, V.A., Brzozowska, M., Czyżewska, U., Glinka, Ł. (2009) Gas chromatographic investigation of phenylpropenoid glycerides from aspen (Populus tremula L.) buds. J. Chromatogr. A 1198-1199, 196-201

Isidorov, V., Szczepaniak, L., Bakier, S. (2014a) Rapid GC/ MS determination of botanical precursors of Eurasian propolis. Food Chem. 142, 101-110

Isidorov, V., Szczepaniak, L., Wróblewska, A., Pirożnikow, E., Vetchinnikova, L. (2014b) Gas chromatographicmass spectrometric examination of chemical composition of two Eurasian birch (Betula L.) bud exudates and its taxonomical implication. Biochem. System. Ecol. 52, 41-48

Isidorov, V.A. (2015) Identification of Biologically and Environmentally Significant Organic Compounds. Mass Spectra and Retention Indices of Trimethylsilyl Derivatives. PWN, Warsaw, 430 pp

Isidorov, V.A., Bakier, S., Pirożnikow, E., Zambrzycka, M., Swiecicka, I. (2016) Selective behavior of honeybees in acquiring European propolis plant precursors. J. Chem. Ecol. 42, 475-485

Isidorov, V.A., Buczek, K., Zambrowski, G., Swiecicka, I. (2017) In vitro study of the antimicrobial activity of European propolis against Paenibacillus larvae. Apidologie 48, 411-422

Julkunen-Tiitto, R., Rousi, M., Bryant, J., Sorsa, S., Keinänen, M., Sikanen, H. (1996) Chemical diversity of several Betulaceae species: comparison of phenolics and terpenoids in northern birch stems. Trees 11, 16-22

Kujumgiev, A., Tsvetkova, I., Serkedjieva, Yu., Bankova, V., Christov, R., Popov, S. (1999) Antibacterial, antifungal and antiviral activity of propolis of different geographic origin. J. Ethnopharmacol. 64, 235-240

Laitinen, M.L., Julkunen-Tiitto, R., Tahvanainen, J., Heinonen, J., Rousi, M. (2005) Variation of birch (Betula pendula) shoot secondary chemistry due to genotype, environment, and ontogeny. J. Chem Ecol. 31, 697-717

Mihai, C.M., Mărghitaș, L.A., Dezmirean, D.S., Chirilă, F., Moritz R.F.A., Schlüns H. (2012) Interaction among flavonoids of propolis affect antibacterial activity against the honeybee pathogen Paenibacillus larvae. J. Invertebr. Pathol. 110, 68-72

Miyagi, T., Peng, C.Y.S., Chuang, R.Y., Mussen, E.C., Spivak, M.S. (2000) Verification of tetracycline resistant American foulbrood pathogen Paenibacillus larvae in the United States. J. Invertebr. Pathol. 75, 95-96

Mutinelli, F. (2003) Practical application of antibacterial drugs for the control of honeybee diseases. Apiacta 38, 149-155

Neuendorf, S., Hedtke, K., Tangen, G., Genersch, E. (2004) Biochemical characterization of different genotypes of Paenibacillus larvae subsp. larvae, a honey bee bacterial pathogen. Microbiology 150, 2381-2390

NIST Chemistry WebBook (2013). National Institute of Standards and Technology, Gaithersburg, MD 20899, http://webbook.nist.gov.chemistry.

Pellegrini, M.C., Alonso-Salces, R.M., Umpierrez, M.L., Rossini, C., Fuselli, S.R. (2017a) Chemical composition, antimicrobial activity, and mode of action of essential oils against Paenibacillus larvae, etiological agent of American foulbrood on Apis mellifera. Biochem. Biodivers. 14, e1600382, 1-18, https://doi. org/10.1002/cbdv.201600382

Pellegrini, M.C, Zalazar, L., Sandra, R., Fuselli, S.R., Ponce, A.G. (2017b) Inhibitory action of essential oils against proteases activity of Paenibacillus larvae, the etiological agent of American Foulbrood disease. Spanish J. Agric. Res. 15, 1-13

Plagemann, O. (1985) A simple culture method for the bacteriological identification of Bacillus larvae on Columbia blood slant agar. Berl. Münch. Tierärztl. Wochenschr. 98, 61-62

Popova, M.P., Bankova, V.S., Bogdanov, S., Tsvetkova, I., Naydenski, C., Marcazzan, G.L., Sabatini, A.-G. (2007) Chemical characterization of poplar type propolis of different geographic origin. Apidologie 38, 393-397

Popova, M., Antonova, D., Bankova, V. (2017) Chemical composition of propolis and American foulbrood: Is there any relationship? Bulgar. Chem. Commun. 49, $171-175$

Raymann, K., Shaffer, Z., Moran, N.A. (2017) Antibiotic exposure perturbs the gut microbiota and elevates 
mortality in honeybees. PLOS Biol., https://doi. org/10.1371/joyrnal.pbio.2001861

R Core Team (2017) R: A Language and Environment for Statistical Computing. Organization: R Foundation for Statistical Computing, Vienna, Austria. (https://www. R-project.org). Accessed 22 Jan 2018

Reyes, M.G., Torres, M.J., Maggi, M.D., Marioli, J.M., Gil, R.R., Sosa, V.E., Uriburu, M.L., Audisio, M.C. (2013) In vitro inhibition of Paenibacillus larvae by different extracts and pure compounds from Flourensia spp. Ind. Crops Prod. 50, 758-763

Santamour, F.S., Jr., Lundgren, L.N. (1997) Rhododendrin in Betula: a reappraisal. Biochem. System. Ecol. 25, 335-341

Santos, R.C.V., dos Santos Alves, C.F., Schneider, T., Lopes, L.Q.S., Aurich, C., Giongo, J.L., Brandelli, A., de Almeida Vaucher, R. (2012) Antimicrobial activity of Amazonian oils against Paenibacillus species. J. Invertebr. Pathol. 109, 265-268

Sikkema, J., de Bont, J.A.M., Poolman, B. (1995).Mechanism of membrane toxicity of hydrocarbons. Microbiol. Rev. 59, 201-222

Simone-Finstrom, M., Spivak, M. (2010) Propolis and bee health: the natural history and significance of resin use by honey bees., Apidologie 41, 295-311

Simone-Finstrom, M., Borba, R.S.; Wilson, M., Spivak, M. (2017) Propolis counteracts some threats to honey bee health. Insects 8(2), 43, https://doi.org/10.3390 /insects 8020046

Skubida, M., Pohorecka, K., Bober, A., Zdańska, D. (2014) Five-year investigation of Paenibacillus larvae expansion in Polish apiaries: Analyses of results, in: Mat. 51th Sci. Beekeep. Conf., Szczyrk, pp. 55-56

Spivak, M.S., Reuter, G.S. (2001) Resistance to American foulbrood disease by honey bee colonies Apis mellifera bred for hygienic behavior. Apidologie 29, 555-565

Versalovic, J., Schneider, M., De Bruijn, F.J., Lupski, J.R. (1994) Genomic fingerprinting of bacteria using repetitive sequence-based polymerase chain reaction. Met. Mol. Cell Biol. 5, 25-40

Wilson, M.B., Brinkman, D., Spivak, M., Gardner, G., Cohen, J.D. (2015). Regional variation in composition and antimicrobial activity of US propolis against Paenibacillus larvae and Ascosphaera apis. J. Invertebr. Pathol. 124, 44-50

Wilson, M.B., Pawlus, A., Brinkman, D., Gardner, G., Hegeman, A., Spivak, M., Cohen, J.D. (2017) 3-Acyl dihydroflavonols from poplar resin collected by honey bees are active against the bee pathogens Paenibacillus larvae and Ascosphaera apis. Phytochemistry, 138, 83-92 